\title{
Review of Barry Hallen's A Short History of African Philosophy, (Second edition 2009)
}

\author{
D.A. Masolo \\ Department of Philosophy \\ University of Louisville, U.S.A. \\ damaso01@louisville.edu OR da.masolo@louisville.edu
}

\author{
Thought and Practice: A Journal of the Philosophical Association of Kenya (PAK) \\ New Series, Vol.3 No.1, June 2011, pp.165-171 \\ thoughtandpractice@gmail.com \\ http://ajol.info/index.php/tp/index
}

Barry Hallen's A Short History of African Philosophy (193 pages), by Indiana University Press, was first published in 2002, and the revised second edition was issued in 2009 in both paperback at US \$24.95, and hardcover at US \$ 75.00 .

Hallen is definitely one of the philosophers whose scholarship has shaped contemporary Englishlanguage African philosophy into a visibly important position within the broader contemporary discourse of the discipline. Many readers comprising scholars and students of all levels alike will most probably have encountered Barry Hallen's work through his earlier and indispensable book, Knowledge, Belief, and Witchcraft: Analytic Experiments in African Philosophy, co-authored with the late J. O. Sodipo and originally published in 1986. A revised second edition was reissued by Stanford University Press in 1997. In 2000 he published The Good, The Bad, and The Beautiful: Discourse about Values in Yoruba Culture (Indiana University Press), followed, in 2006, by African Philosophy: The Analytic Approach (Africa World Press). The latter explains how, in defiance of the subtle separations of the schools of thought in the Western tradition, analytic philosophy still remains a viable methodological tool for sifting meanings out of the various expressive domains within a cultural realm, a practice that leads the philosopher in the African context to engage in observations that, in Western traditions, are usually associated with the methods applicable in the social sciences. 
Hallen's work is driven by a firm belief, grounded in the analytic tradition of philosophizing, that philosophical problems, mainly about the nature of meaning as it straddles epistemology and linguistics or philosophy of language, stem primarily from paying careful attention to how people use both ordinary and specialized language such as is reserved for expressing religious beliefs, to either suggest or to make theoretically significant claims or assertions about their apprehension of the state of affairs in the external world and their experiences of them, or to emphasize values around which the practice of life is organized. These matters lend human language, whether ordinary or the specialized language of the beliefs and practices organized around rituals, to the keen ear of the philosopher for analysis and explication. The latter suggests a different approach for the professional philosopher: to discuss the claims with those who make them for further understanding of the meanings involved or put in focus in those claims and assertions, and these (meanings) are then carefully put into a comparative conversation with those, in the Western philosophical tradition, that portent to address conceptual issues within the general realm as the African assertions. Hallen and Sodipo followed the latter approach in their conversations with the Yoruba Onisegun, the teachers and healers. The result of their conversations is what they projected as a trilogy, two of which are in print already, namely, Knowledge, Belief and Witchcraft, and The Good, The Bad, and The Beautiful, both listed above. As I understand it, the third and final volume of the trilogy is currently in the works.

A Short History of African Philosophy, whose first edition was published in 2002, is a different book from all those listed above. First, it is a recapitulation of the major debates that have characterized contemporary philosophical thought and practice in the English-speaking Africa beginning, as Hallen himself situates them, with the publication of the English translation of Placide Tempels' now-widely discussed book, Bantu Philosophy, in 1959. From then on, the idea of an African philosophy took a life of its own, enjoying an early popularization in the works of scholars such as Janheinz Jahn (Muntu, 1961) and John S. Mbiti (African Religions and Philosophy, 1969). Besides these two general, sympathetic and popular receptions of Tempels' work and their claims about the locus of African philosophy in their beliefs and customs, both the subsequent discussion of Tempels and the practice of philosophy generally has been very different in English-speaking African academies from how the development of the same matters shaped up under the handling of their French-speaking neighbors and colleagues. 
If historians are bearers of the many lenses through which we look at and thread together different events through time, then Hallen's A Short History of African Philosophy is a lesson in the plurality of histories, as it evinces this as much in the story it tells as in what it leaves out. In other words, Hallen's focus is the growth of philosophical thought and practice in Africa as shaped through engagements with other philosophical trends and discourses dominant in the global English-speaking world with which African philosophers became acquainted through the paths paved by the lines of the British colonial map and education. Thus, although he is probably aware, Hallen does not tackle Tempels' own use of anti-Cartesian currents, drawn from the reservoir of Bergsonian philosophy current in France at the time, in reference to the idea of the "vital force", and of "intuition as a mode of knowing" which he used as both the causal explanations of the behavioral patterns of the Baluba (Luba peoples) of the Shaba region and their "implicit philosophical understanding". Nor does he refer to the earlier (pre-Hountondji) African philosophers' critical commentaries on Tempels and the birth of their own brand of ethnophilosophy such as one sees in the works of Alexis Kagame and others, for example. Rather, Hallen starts by charting the reaches of rationality as a cognitive capacity of humans with both universal and culturally specific manifestations in its order and applications, respectively. Specifically, the discussion of rationality under the rubrics of universality and relativism finds its traces to the now-defunct debate, originated in the United Kingdom largely as a reexamination of the implications to British neopositivism of E. E. Evans-Pritchard's now classic study of the Azande, namely, Witchcraft, Oracles, and Magic among the Azande (1937), about what counts as a rational account of causal relations between things or observable states of affairs in the world. This debate had been occasioned by Peter Winch's 1964 essay, "Understanding a Primitive Culture", in which he was critical of Evans-Pritchard's own critique of Azande handling of culpability in witchcraft accusations as overlooking the obvious logical inference from their basic premises. Above all, however, Evans-Pritchards's general evaluation of the Azande scheme was based on the unilateral dependence on empirical knowledge as the only warranted basis for making assertions about reality. The so-called "rationality debate" reproduced this monolithic positivist stance by trying to trash anything that did not conform to their rubric. An example is the widely discussed - quite critically - work of Robin Horton, a member of the group at the center of the seminars on rationality at Oxford. Over the years, Hallen has established himself as the leading critic of Horton and, by extension, of EvansPritchard's views and arguments which Horton fervently defended from a positivistic point of view. 
The point is clear. The focus of A Short History of African Philosophy is an account of the growth of, and some of the major themes in, the English-speaking philosophy in the African context. In recent years, this discourse has expanded beyond the strictly English-speaking circles or themes traditionally associated with the practice of philosophy within that general intellectual lineage. Since 1983 or thereabout, English-speaking African philosophy and its audiences have embraced or included the thoughts and works of some African philosophers from Frenchspeaking nations which, thanks to the mediation of translators and publishers in the United States where African philosophy has made a significant academic impact and presence, have become an essential part of the resources for the school of thought. Prime examples of such crossing are the works of V.Y. Mudimbe and Paulin J. Hountondji. In the meantime, other French-speaking African philosophers, such as Souleymane Bachir Diagne and Jean-Godefroy Bidima, are joining in as the pack expands, and are providing the needed evidence for diversity in African thought. Together, these scholars are responsible for bringing to English-speaking readers both themes and literary styles typically associated with Francophone thinking in their African manifestations. Although A Short History of African Philosophy does not include an account of the works of any of the pioneer French-speaking African philosophers, like Alexis Kagame, Fabien EboussiBoulaga, Stanislas Adotevi, or Marcien Towa - to mention only four whose names are often easily remembered in English-speaking circles - or those from the younger generation like the two mentioned above, ostensibly because their works have not been translated into English and, therefore are not part of discourse by people who philosophize in that language, its inclusion of some discussion of the works of both Hountondji and Mudimbe is a significant step to inclusiveness across the linguistic divide.

However minimal, Hallen's trans-lingual inclusiveness is significant in that achievement as much as in what it exemplifies as a potential for broadening mutual awareness and debates across the lines of demarcation between the language conclaves of African intellectual traditions. One can, for example, contrast $A$ Short History of African Philosophy with Grégoire Biyogo's Histoire de la philosophie africaine, Livre II (l'Harmattan, 2006) which makes no mention of any work in African philosophy in the English language nor of any English-speaking African philosopher other than when he lists some philosophers by their countries of origin (pp.216-7). This means that whether it is imposed by language or by the traditions of thought we write from, the limitation characteristic of Hallen's work is not unique to it, but it certainly is an obstacle to a 
more integral view of African philosophy and to the formation of a more robust and more comprehensive or linguistically inclusive debate and growth of the tradition of the discipline in institutions there. In the meantime, the tradition must be taught, and the gaps closed with notes and references. For this goal, A Short History of African Philosophy is an excellent tool. It is clearly written, and the threads connecting the authors and materials presented are woven with clarity and precision. Its comprehensive bibliography stands as a worthy resource in and of itself. For audiences not deeply acquainted with African philosophy - the subject matter of the book this will be a valuable asset as a highly accessible and easy reference not only for the undergraduate student, but also for the graduate student and researcher who needs quick references for positions held by the different authors and thinkers discussed therein. Besides being unsurpassable on the grounds of its historical approach and comprehensive bibliography, it compliments Samuel Oluoch Imbo's Introduction to African Philosophy (1998).

I should add, in conclusion, that even as book prices continue to be affected upwards just like most other things in the current state of world economy, students and scholars of African philosophy, and of African studies generally, should find the expense on this book a worthy investment.

\section{References}

Bidima, Jean-Godefroy. 1995. La philosophie négro-africaine. Paris: Presses Universitaires de France.

Biyogo, Grégoire. 2006. Histoire de la philosophie africaine, Livre II: Introduction a la philosophie moderne et contemporaine. Paris: 1'Harmattan.

Diagne, Souleymane Bachir. 2008. Comment philosopher en islam? Fenton, MI.: The Phoenix Publishing Company.

Evans-Pritchard, E.E. 1937. Witchcraft, Oracles, and Magic among the Azande, Oxford, 
Clarendon Press.

Hallen, Barry and J. Olubo Sodipo. 1997. Knowledge, Belief, and Witchcraft: Analytic Experiments in African Philosophy. Revised Ed., Stanford, Clif.: Stanford University Press.

Hallen, Barry. 2000. The Good, The Bad, and The Beautiful: Discourse about Values in Yoruba Culture. Bloomington: Indiana University Press.

--. 2006. African Philosophy: The Analytic Approach. Trenton, NJ: Africa Worl Press.

--. “A Philosopher's Approach to Traditional Culture”. Theoria to Theory, Vol.9 No.4, pp. 25972.

--. 1996. “Analytic Philosophy and Traditional Thought: A Critique of Robin Horton". English, Parker and K.M. Kalumba eds. African Philosophy: A Classical Approach. Englewood, NJ: Prentice Hall, pp. 216-28 .

Horton, Robin. 1967. “African Traditional Religion and Western Science”. Africa, Vol.37 Nos.12, pp.50-71 and 155-187. Reprinted as "African Traditional Thought and Western Science" in Wilson, B.R. ed. 1970. Rationality. New York: Harper and Row, pp.131-71. Hountondji, Paulin J. 1977. African Philosophy: Myth and Reality (English transl. Henri Evans with the collaboration of Jonathan Ree), Bloomington, Indiana University Press, 1983 (second edition, 1996); original French edition: Sur la "philosophie africaine." Critique de l'ethnophilosophie, Paris, François Maspero,.

Imbo, Samuel Oluoch. 1998. An Introduction to African Philosophy. New York: Rowman and Littlefield.

Jahn, Jenheinz. 1961. Muntu: An Outline of the New African Culture, New York: Grove Press. Kagame, Alexis. 1956. La philosophie bantu-rwandaise de l'être. Bruxelles: Académie Royale des Sciences Coloniales.

Mbiti, John S. 1969 African Religions and Philosophy. London: Heinemann Educational Books. Mudimbe, V.Y. 1988. The Invention of Africa, Bloomington: Indiana University Press.

Tempels, Placide. 1959, 1969. Bantu Philosophy. King, Colin trans. Paris: Présence Africaine. Original French edition La philosophie bantoue, Elizabethville: Lovania, 1945; Paris: Presence Africaine, 1949 and $\left(3^{\text {rd }}\right.$. edition) 1965.

Wilson, B.R. ed. 1970. Rationality. New York: Harper and Row. (Oxford, Blackwell, 1974).

Winch, Peter. "Understanding a Primitive Culture”. American Philosophical Quarterly, Vol.I, pp.307-24. 